\title{
THE OLD IRISH EVIDENCE FOR THE RECONSTRUCTION OF THE INDO-EUROPEAN ACROSTATIC PRESENTS
}

\author{
NATALIA O'SHEA
}

\section{Introduction: Ablaut-accent types}

The present article reveals a small part of our ongoing work, which aims at a thorough analysis of the evolution of IE verbal morphological categories and formal types of verbal stems in Celtic.

We chose to follow the Erlangen School traditions and thus to posit a number of distinct ablaut-accent types in the verbal system, as well as in the nominal system. To begin with, we shall give a laconic overview of the types in question. The following types are reconstructed, given that word formations usually consist of root, flexion and, optionally, suffix or infix.

\subsection{Proterokinetic type}

The root is stressed and displays full grade ablaut in the strong stem, while the unstressed affix and flexion are in the zero grade. The accent in the weak stem shifts onto the affix, which acquires a full grade, and the root, accordingly, assumes the zero grade, e.g. IE * ${ }_{s} u h_{2} d-u$ - "sweet"; Acc. Sg.

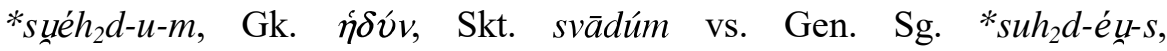
Gk. $\dot{\eta} \delta \dot{\varepsilon}(F) o \varsigma$, Skt. svādós.

\subsection{Amphikinetic type}

In this case the affix (if there at all) is invariably unstressed and is naturally in the zero grade (it might also, as illustrated below, show a secondary $o$ vocalism); the strong stem is manifested by the full-grade stressed root, and the weak one shows the full-grade stressed flexion, while the root, as expected, shows the zero grade ablaut again, e.g. IE *unek-nt- "willing"

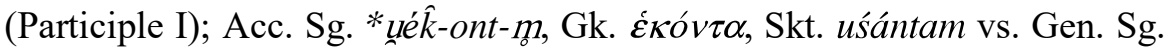

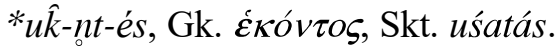

\subsection{Histerokinetic type}

This type always shows a zero-grade unstressed root: the ablaut-accent shift takes place between the affix and the flexion, e.g. IE *urg-n- "lamb", *uks-n-

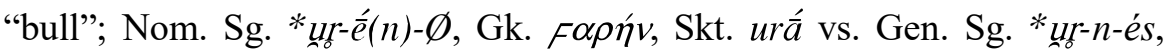
Gk. (F) پ’ovós, Skt. ukṣnás. 


\subsection{Acrostatic type}

In addition to these three kinetic types, most scholars agree on the existence of an acrostatic one, which does not show a shift of stress but still has a quantitave and/or qualitative ablaut shift. The typical examples of this type are heteroclitic nominal stems, e.g. IE *und-r/n- "water"; Nom. Sg. *uód-rio, Hitt. unadar vs. Gen. Sg. *uéd-ñ-s, Hitt. unedenaś (Herzenberg 1989: 41).

Without going into details of the sources of the last type, we should point out that most kinetic ablaut/accent paradigms show a tendency of shifting the stress and full grade towards the end of the word in the weak stems. This tendency was beautifully coined "the rule of ablaut-accent shift to the right" by Konstantin Krasukhin (1998: 36).

\subsection{Application of Erlangen classification to verbal formations}

The lovely Erlangen classification can very well be applied to verbal formations. In this case, root presents can be described as amphikinetics, as they demonstrate the ablaut-accent shift from root to flexion, e.g. IE $g^{u h} e^{u} n-/ g^{u h} n$ - "wound, slay", Hitt. 3 Sg. kuenzi, 3 Pl. kunanzi.

Nasal-infixed presents seemed to belong mostly to the histerokinetic type, where a full-grade infix is characteristic of the strong stem, e.g. IE *iu-né-g-/*iu-n-g- “join, bind”, Skt. 3 Sg. yunákti, 3 Pl. yuñjánti.

Johanna Narten (1968) was the first to describe an acrostatic version of IE present stem, where the root of the strong stem shows a lengthened grade under stress, and the weak stem root shows the normal grade, e.g. IE *h $h_{1} \bar{e} d-/ h_{1}$ éd- "eat", Hitt. 1 Sg. édmi, 3 Pl. adanzi. It should be noted in this case that, despite the fact that there is no formal shift of stress here from root or affix to flexion, this type of ablaut still conforms to "the rule of ablaut-accent shift to the right". The idea is that the lengthened grade root in the strong stems of the acrostatic type corresponds to the normal grade in the weak stems just as the normal full grade root in the strong stems of the amphikinetic type corresponds to the zero grade root in the weak stems. In other words, what we see here is a difference of two ablaut models by one quantitative degree.

The origins of the lengthened grade in the strong stems of acrostatic paradigms (which, apart from Narten-presents, also include sigmatic aorist indicative, which we analyse elsewhere), is commonly explained by a secondary lengthening; the source for this is the analogy with the amphikinetic models. It is assumed that an acrostatic athematic paradigm with a normal grade in the weak stem "restores" the proportion by lengthening the root vowel in the strong stem. As applied to sigmatic aorist, this process was neatly explained by J. Kuryłowicz (1956: 358-363), who 
showed the inductive role of aorist from TET-roots in this case. A full-on zero grade from these roots is phonotactically impossible, which means that there should happen an epenthesis of a vowel between the root consonants and a subsequent restoration of a full grade in the weak stem: $\dagger T T-s-\sim$ ${ }^{*} T_{E} T-s->T E T-s-$. In turn, the opposition of the strong stem to the weak is renewed by the lengthening of the strong stem root vowel: $T \bar{E} T-s-$. Sigmatic aorist paradigms from other roots, as well as a few other structures, follow this pattern. Klaus Strunk, who did an analysis of ablaut in acrostatic verbal paradigms, including Narten-presents and sigmatic aorists, calls the ablaut lengthening shift "Aufstufung" (Strunk 1985).

It should be remembered that verbal categories of present and aorist are closely related and can be brought together as one "infect" system. Indeed, both these forms denote action, though they differ aspect-wise; the aorist corresponds to the very notion of perfective aspect, that is, the action itself in the core of its semantics, while the present corresponds to imperfective aspect, and its semantics imply the ideas of iterativity and processivity ( $c f$. Schmidt 1974; Giannakis 1997: 22-30).

Antoine Meillet's theory of original differentiation of aorist and present verbal stems in accordance with the semantics of stem roots is still relevant. This theory implies that if the root semantics convey the notion of iterativity or process, this root allows a construction of primary present stem; if the root only denotes action as it is, it develops a primary aorist stem. This hypothesis is corroborated by the tendency of simple root aorists to correspond to embellished nasal- or otherwise infixed or reduplicated presents at a later stage, when every verbal root develops stems of various temporality and aspect. Thus, K. Strunk (1967) observed a clear correlation of root aorists and nasal-infixed presents. On the other hand, a simple amphikinetic root present normally corresponds to a more complex (sigmatic in most cases) aorist. It seem logical that present stems show greater variety than aorist in their affixation and other extra markers, and the examples of the type "root present - embellished aorist" are a lot rarer. The aorist, as a form denoting action per se, could be formed from practically every root, while the development of primary present required the root to possess the aforementioned semantics of iterativity or, at least, the possibility of development of such semantics. In other words, as Meillet puts it, "present roots" can very well form both aorist and present, while "aorist roots" only form aorists that give the Present system certain limits.

We shall dwell now on a few main features of the mechanism of unification of IE kinetic paradigms in Celtic. Present stems are perfect for illustration of these processes, as they show the most diverse kinetics in the Indo-European verbal system. 
The main principle of verbal thematisation in Celtic is the generalisation of the weak stem of the kinetic paradigm; this principle is practically unaffected by the kinetic type of the stem in Indo-European. However, there is a number of developments which precede thematisation. One of these is the analogous leveling of personal forms within the weak stem in the cases of different development of a root nasal in dependence with the environment, cf. 3 Pl. $g^{u h} n$-énti $>{ }^{*} g^{u}$ nenti $\sim{ }^{*} g^{u}$ anenti under the influence of $1 \mathrm{Pl} .{ }^{*} g^{u h} n$-mós, $2 \mathrm{Pl} .{ }^{*} g^{u^{h}} n$-té $>{ }^{*} g^{u}$ anmos, ${ }^{*} g^{u}$ antes (OIr. gonaid "wounds, kills"). Another kind of leveling which often precedes the complete unification of a paradigm is the simplification of the ablaut opposition of quantity and quality in favour of the opposition of quality only, cf. ${ }^{*} h_{1} \bar{e} d-t i$ vs. ${ }^{*} h_{1} e ́ d-n t i>3 \mathrm{Sg}$. ${ }^{*} i t^{s}-t i$ vs. $3 \mathrm{Pl}$. ${ }^{*} e d-a n t i \sim{ }^{*} i t^{s}-t i$ vs. *id-anti (OIr. ithid "eats").

Finally, the elimination of the ablaut-accent opposition of stems and unification of the paradigm can happen in two ways. First, by thematisation per se, which implies the insertion of a thematic vowel between the stem and the flexion, cf. ${ }^{*} g^{u}$ enti vs. ${ }^{*} g^{u}$ anenti $\sim{ }^{*} g^{u}$ aneti, ${ }^{*} g^{u}$ anonti. Second, as seen in nasal presents, the role of the thematic vowel can be easily assumed by a new suffix, which evolved, in turn, as a result of resegmentation of the original stem, cf. *mrs-né- $h_{2}-t i$ vs. *mr-n- $h_{2}$-énti $>*$ marnāti vs. *marnanti *mar-na-ti, *mar-na-nti (OIr. marnaid "betrays").

These two types of unification appear very similar at the first sight, but there is a profound difference between them, as far the shapes of stems are concerned. Celtic seems to follow the archaic oxytone model (the tudáti type) in the thematisation, and can be compared to Greek and Indo-Iranian in this sense. On the other hand, as the analysis of amphikinetic nasal "Strunk-presents" show, the generalisation of the weak stem is not obligatory for paradigms that undergo unification by suffixation: cf.

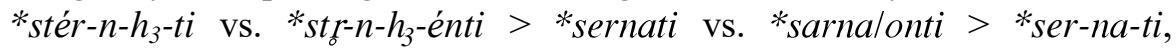
*ser-na-nti (OIr. sernaid "spreads"). Moreover, the vocalism of the reflexes of nasal presents in Celtic can be successfully used as a criterion for the determination of the kinetic type of the corresponding amphikinetic or hysterokinetic present formation in the proto-language.

Thus, our investigation focuses on the Old Irish vestiges of IndoEuropean Narten-present forms. The number of reconstructed IndoEuropean Narten-forms is quite limited; therefore it should not be surprising that Celtic only shows a handful of reflexes of these stems, which underwent more or less significant changes in the course of thematisation.

All of these are found in Old Irish, which explains the apparent narrowness of the topic that was chosen for this article. Unfortunately, we 
have no evidence for these stems in British or Continental Celtic (apart from the first one, on which see below), and the Old Irish, as the "Sanskrit of Celtology", as H. Pedersen coined it, proves to be the most valuable language source again indeed.

\section{The analysis}

We shall begin with the verb ithid "eats", class B I (GOI), S1a (EIV), W. ys from IE root * $h_{1} e d$ - (IEW 287-9). H. Pedersen attempted to treat this verb as a derivative from the OIr. verbal noun ithe $<*$ pit-eieh from the root *pei(t) (VKG II 559), but this theory proves to be flawed, as the whole of the verbal paradigm in question shows that we are dealing with one of the original strong verbs: Subj. $3 \mathrm{Sg}$. -es $<* h_{1}$ ed-selo-, Fut. $3 \mathrm{Sg}$. -is $<* h_{1} i-h_{1} d$ selo-, Pret. 3 Sg. -dúaid $<*$ de- uno-āde $<* h_{l} e-h_{1}$ ód-e (Schumacher 1998; LIV 205).

A "Narten-present" is reconstructed for the root $* h_{1} e d$ - on the basis of the evidence from Hitt. 1 Sg. édmi, 3 Pl. adanzi "eat" (Oettinger 1979: 89-91), Skt. $3 \mathrm{Sg}$. átti, $3 \mathrm{Pl}$. adánti (with ablaut levelling *átti > *átti) (McCone 1991 : 6), Hom. Gk. Inf. ع́ $\delta \mu \varepsilon v \alpha \imath$ (Rix 1992: 83), Lat. 1 Sg. edō, 3 Sg. esst (Meiser 1998: 223-224), Goth. itan etc. (Isebaert 1992: 194-196; LIV 205). The ablaut of all reflexes of this stem is rather difficult to account for; moreover, we have to take into account the Indo-European word for "tooth", which is commonly regarded as a frozen active participle with a zero-grade root - IE *Hdént-s. Martin Kümmel in his article in LIV proposes a reconstruction of two variants of the stem in question - an amphikinetic one with a meaning "to bite, gnaw" and an acrostatic one with a meaning "to eat". The meaning "to eat" in this case turns out to be derivative, as well as the acrostatic ablaut-accent type, which conforms to the principle of evolution of such stems, as was shown earlier. The evidence from Celtic seems especially significant here, as it can prove that the acrostatic structure can be traced back as far as the Indo-European.

We reconstruct the Proto-Celtic paradigmatical opposition as $3 \mathrm{Sg}$. ${ }^{*} i t^{s}-t i$ vs. $3 \mathrm{Pl} .{ }^{*} e d$-anti, where ablaut opposition undergoes leveling in favour of quantity only: ${ }^{*} i t^{s}-t i$ vs. ${ }^{*} i d$-anti; the difference in consonants makes the influence of the suppletive verbal noun ithe $<*$ itii $\bar{a}<{ }^{*}$ pit-ieh possible, which triggers the change $* i d-\sim * i t$ - throughout the paradigm; finally, the whole paradigm is thematised and the weak stem is generalised: *it-e-ti vs. *it-o-nti > OIr. 3 Sg. ithid, 3 Pl. ethait. Welsh cognate, 3 Sg. ys, is obviously a reflex of *ed-ti with the normal grade, that is, an innovation similar to Skt. átti as mentioned above (LIV 205 n. 9). The next verb in this group is OIr. rigid "stretches, rules", class B I (GOI), S1a (EIV 43), from IE root *h$h_{3}$ reg- (IEW 854-857). 
It should be mentioned straight away there there exist two different verbal stems in Old Irish: one is seen in OIr. at-raig "stretches, gets up", which forms a non-reduplicating $S$-future ress-, a subjunctive homonimous to the future and a $T$-preterit recht; it obviously goes back to the root * $h_{3}$ re $\hat{g}$ - as well; on the other hand, the verbal stem seen in con-rig "binds" has a subjunctive réss-, reduplicating future ririss- and reduplicating preterit reraig (cf. Dillon 1971; VKG II 592-596). The last stem goes back to the IE root * reig- (IEW 862) and does not have anything to do with the Narten-presents discussed here; nonetheless, the simple verb rigid with its syncretic semantics and other forms corresponding to con-rig (DIL R 68.4ff; LEIA R-13-15) posits a problem. M. Kümmel tends to identify the simplex with the compound verb stem, but the semantic shift seems hardly plausible (LIV 455). Notwithstanding the difference in tense and mode forms, the idea to connect rigid and at-raig seems more promising. We shall not dwell on the peculiar vocalism of our verb, which has been discussed elsewhere (Cowgill 1983: 98; McCone 1991 : 9). Be that as it may, we can more or less easily derive our verb from an Indo-European Narten-present ${ }^{*} h_{3} r \bar{e}^{\prime} \hat{g}-t i$ vs. ${ }^{*} h_{3} r e ́ \hat{g}-n t i($ LIV 270) and assume a scenario of evolution identical to that of the verb ithid: ${ }^{*} h_{3} r \bar{e} \hat{g}-t i$ vs. ${ }^{*} h_{3} r e ́ g-n t i>* r i \chi-t i$

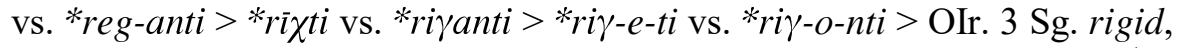
3 Pl. regait (McCone 1991 : 10). Thus, this verb corresponds to Skt. rásțti "rules" and maybe Goth. rikan "to heap". The contamination with con-rig happened some time in the course of the development of the Old Irish language, which led to the replacement of the original set of forms by a borrowed one.

As for the compound at-raig, it seems logical to compare it to Lat. rego "rules" < ${ }^{*} h_{3} r e ́ g-e / o-$, as well as to Gaul. regu-c "I straighten" from the Chamalières inscription (McCone 1991 root vowel is lowered in accordance with the rule of Archaic Irish phonetics, which implies that a stressed $e$ is lowered into $\alpha$ before $\gamma^{(u)} e / i$, cf. OIr. Nom. Sg. daig "fire" $<*^{*} d a \gamma^{u} i h<* d e g^{u} i s$ vs. Gen. Sg. dego $<* d e \gamma^{u} \bar{o} h$ $<{ }^{*} \operatorname{deg}^{\mu} \bar{O} s$ (McCone 1996: 111). We can restore a thematic present on the Indo-European level - not as an original formation, but rather as an innovation, for example, a transition of an original subjunctive into the indicative realm. We believe that rigid and at-raig fall into one etymological area quite neatly.

The Old Irish verb mligid "milks", class B I (GOI), S1a (EIV) from IE root $h_{2}$ melg- (IEW 722-723) is the last of the known verbs which can be formally regarded as a vestige of an original Narten-present, even though the Indo-European stem in question is somewhat flawed. 


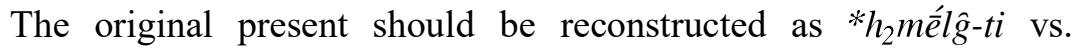
* $h_{2}$ mélg $-n t i$, but the strong stem Skt. 3 Sg. márș̣ti "scrubs, cleans" corresponds to the weak stem $3 \mathrm{Pl}$. mrjánti, that is, an amphikinetic-type weak stem: *h $h_{2} m$ lg-énti (Narten 1968: 16; LIV 249 n. 2). On the other hand, Av. marazaiti "touch" demonstrates thematisation of the original weak stem with the expected mornal grade root: IIr. ${ }^{*}(H)$ már $\breve{-}<* h_{2}$ mélg (LIV 249 n. 3); the same can be applied to Gk. $\dot{\alpha} \mu \varepsilon \dot{\lambda} \lambda \omega \omega$ "I milk", as well as OE. melcan. Nonetheless, the development of the Old Irish verbs follows the Sanskrit pattern, and we have to posit a remodeling of an acrostatic

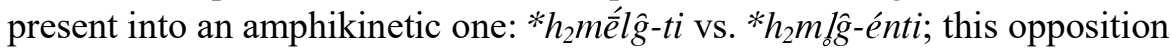
gives Common Celtic *melxti vs. *mliyenti with the regular development of syllabic $l>l i$ before a stop, and the usual Celtic thematisation with the generalisation of the strong stem ensues: ${ }^{*}$ mli $\gamma$-e-ti vs. ${ }^{*} m l i \gamma-o-n t i>$ OIr. 3 Sg. mligid, 3 Pl. mlegait (SnG 137).

Finally, the last verb which we have included in this group can only be considered a vestige of an acrostatic Narten-present on the basis of the evidence from other Indo-European languages. This is OIr. midithir "judges", deponent verb class B II (GOI 354), S2 (EIV 75), from IE root *med- (IEW 705-706). The evidence of Gk. $\mu \eta \dot{\delta} \delta \mu \alpha \imath$ "I think, I ponder" (with the secondary restoration of the lengthened grade in the middle voice) allows positing a Narten-present for this root: IE *méd- vs. méd- (Isebaert 1992: 201). Another indirect evidence in favour of the acrostatic present reconstruction is provided by Lat. medeor "I help", comoing from an essive * $m_{e} d$-h $h_{1} i e$ - (LIV 380), where a zero grade root restores an epenthetic $e$ instead of the usual $\partial_{2}>a$, cf. Lat. madeō "I am [getting] drunk" $<{ }^{*} m_{e} d$ $h_{l} i e$ - from the root *med- 2 "to be full, satiated" (LIV 380-381).

The Old Irish preserved the tendency for the formation of a middle paradigm, which means that its present is based on the weak stem by default; this stem is furnished with an ie/o-suffix, which is common in strong deponent verbs: *med-ie-tor $>*_{m e}$ - - -tor $(i)>\mathrm{OIr} .3 \mathrm{Sg}$. midithir. Frankly speaking, this verb in Old Irish per se cannot be regarded as a valuable piece of evidence for the reconstruction of acrostratic presents in Indo-European, but its cognates in other languages point in the direction of such possibility, and therefore we decided to include its analysis in the present paper.

\section{Conclusion}

We have analysed a small number of Old Irish verbs which show traces of acrostatic Present formations. However limited the Celtic evidence may be, the importance of it should be under no circumstances downplayed. 
This evidence from the Western dialects of the Indo-European periphery provides a strong point for the argument that acrostatic Presents existed at least at a later stage of the Indo-European proto-language.

Moscow State University, Russia

\section{Abbreviations}

DIL - Quin, E. G., ed., 1983, Dictionary of the Irish Language based mainly on Old and Middle Irish materials; Compact edition, Dublin: RIA.

EIV - McCone, K. R., 1997, The Early Irish Verb, Maynooth: An Sagart.

GOI - Thurneysen, R., 1946, A Grammar of Old Irish, Dublin: DIAS.

IEW - Pokorny, J. 1959, Indogermanisches etymologisches Wörterbuch, Bern, München: Francke Verlag.

LEIA - Vendryes, J. Lexique étymologique de l'irlandais ancien. A Dublin: DIAS 1959; M N O P - Dublin 1960; R S - Dublin - Paris: Centre National de la Recherche Scientifique 1974. Par les soins de E. Bachellery et P.-Y. Lambert: T U - Dublin - Paris 1978; B - Dublin Paris 1980; C - Dublin - Paris 1987, D - Dublin - Paris 1996.

LIV - Rix, H., Kümmel, M., Zehnder, T., Lipp, R., Schirmer, B., eds., 1998, Lexicon der indogermanischen Verbum, Wiesbaden: Ludwig Reichert Verlag.

SnG - McCone, K. R., McManus, D., Ó Háinle, C., Williams, N., Breatnach, L., eds., 1994, Stair na Gaeilge, Maynooth : An Sagart.

VKG - Pedersen, H., 1909-1913, Vergleichende Grammatik der keltischen Sprachen, Göttingen: Vandenhoeck \& Ruprecht.

\section{References}

Cowgill, W., 1983, 'On the Prehistory of Celtic Passive and Deponent Inflection', Ériu 34, 73-112.

Dillon, M., 1971, 'Irish dérgaid 'spreads (coverings), makes a bed', Celtica 9, 205-209.

Giannakis, G. K., 1997, Studies in the Syntax and Semantics of the Reduplicated Presents of Homeric Greek and Indo-European, Innsbrucker Beiträge zur Sprachwissenschaft 90, Innsbruck: Institut für Sprachwissenschaft der Universität Innsbruck. 
Herzenberg, L. G., 1989. 'Problemy akcentologičeskoij rekonstrukcii' [The Problems of Accentological Reconstruction], in: Sravnitel'noistoričeskoe izučenie jazykov različnyx semej: rekonstrukcija na otdel'nyx urovnjax jazykovoj struktury [Comparative and Historical Study of Languages of Different Families: Reconstruction on Separate Levels of Language Structure], Moscow: Nauka.

Isebaert, L., 1992, 'Spuren akrostatischer Präsensflexion im Lateinischen', in Panagl, O., and Krisch, T., ed., Latein und Indogermanisch: Akten des Kolloquiums der Indogermanischen Gesellschaft (Salzburg, 23-26 September 1980), Innsbrucker Beiträge zur Sprachwissenschaft 64, Innsbruck: Institut für Sprachwissenschaft der Universität Innsbruck, 193-205.

Krasukhin, K. G., 1998, 'Akcentologija v predystorii indoevropejskix jazykov' [Accentology in the Prehistory of Indo-European Languages], Voprosy Jazykoznanija 6, 11-38.

Kurylowicz, J., 1956, L'Apophonie en indo-européen, Wrocław: Zakład Imienia Ossolińskich, Wydawnictwo Polskiej Akademii Nauk.

Lambert, P.-Y., 1997, La langue gauloise, description linguistique, commentaire d'inscriptions choisies, édition revue et augmentée, Paris: Éditions Errance.

McCone, K. R., 1991 Presents, Subjunctives and Futures, Innsbrucker Beiträge zur Sprachwissenschaft 66, Innsbruck: Institut für Sprachwissenschaft der Universität Innsbruck.

McCone, K. R., 1991 b, 'OIr. -ic 'reaches', ithid 'eats', rigid 'stretches, directs, rules' and the PIE 'Narten' Present in Celtic', Eriu 42, 1-12.

McCone, K. R., 1996, Towards a Relative Chronology of Ancient and Medieval Celtic Sound Change, Maynooth: An Sagart.

Meiser, G., 1998, Historische Laut- and Formenlehre der lateinischen Sprachen, Darmstadt: Wissenschaftliche Buchgesellschaft.

Narten, J., 1968, 'Zum 'proterodynamischen' Wurzelpräsens', in: Heesterman, J. C., Schokker, G. H., Subramoniam, V. I., eds., Pratidānam: Indian, Iranian and Indo-European studies presented to Franciscus Bernardus Jakobus Kuiper on his sixtieth birthday, The Hague: Mouton, 9-19.

Oettinger, N., 1979, Die Stammbildung des hethitischen Verbums, Nürnberg: Hans Carl.

Rix, H., 1992, Historische Grammatik des griechischen, Darmstadt: Wissenschaftliche Buchgesellschaft.

Schmidt, K. H., 1974, 'Das Verbum im Keltischen: sprachgeschtichtiliche Grundlagen und typologische Entwicklung', ZCP 33, $28-44$.

Schumacher, S., 1998, 'The Preterit of ithid 'eats', Ériu 49, 149-160. 
Strunk K., 1967, Nasalpräsentien und Aoriste. Ein beitrag zur Morphologie des Verbums im Indo-Iranischen und Griechischen, Heidelberg: Carl Winter.

Strunk, K., 1985, 'Flexionskategorien mit akrostatischem Akzent und die sigmatischen Aoriste', in: Schlerath, B., Rittner, V., eds., Grammatische Kategorien: Funktion und Geschichte: Akten der VII. Fachtagung der Indogermanischen Gesellschaft, Wiesbaden: Ludwig Reichert Verlag, 490-514. 